\title{
Specific IgE responses in patients allergic to goat's milk but tolerant to cow's milk: involvement of minor differences in primary structure between caprine and bovine caseins
}

\author{
Sandrine Ah-Leung ${ }^{1}$, Fany Blanc ${ }^{1}$, Stéphane Hazebrouck', Karine Adel-Patient ${ }^{1}$, Evelyne Paty ${ }^{2}$, Pierre Scheinmann², \\ Jean-Michel Wal ${ }^{1}$, Hervé Bernard ${ }^{1 *}$
}

From Food Allergy and Anaphylaxis Meeting 2011

Venice, Italy. 17-19 February 2011

\section{Background}

Allergy to goat's milk (GM) proteins in patients tolerant to cow's milk (CM) is nowadays often observed whereas $\mathrm{CM}$ allergy was generally associated with a cross allergy to GM. We aimed to analyse the specific IgE response in patients allergic to GM but tolerant to $\mathrm{CM}$ and to compare this response to that observed in patients allergic to both milks.

\section{Methods}

$\beta$-Lactoglobulin, whole casein and its four different fractions, i.e. $\alpha$ s1-, $\alpha$ s2-, $\beta$ - and $\kappa$-caseins, were isolated from raw CM and GM. Purified $\beta$-caseins were subjected to a mild proteolysis by plasmin which generated 3 peptides, i.e. $\mathrm{f}(1-28), \mathrm{f}(29-107)$ and $\mathrm{f}(108-207 / 9)$. Synthetic peptides partially recovering the N-terminal $\mathrm{f}(29-$ 107) part of the caprine $\beta$-casein were also produced. Immunoreactivity of the purified proteins and peptides was assessed by IgE binding studies using sera from 12 GM-allergic patients tolerant to $\mathrm{CM}$ and $10 \mathrm{CM}$-allergic patients. The capacity of bovine and caprine milk proteins to induce the degranulation of humanized rat mast cells passively sensitized with human specific IgE was also evaluated.

\section{Results}

In patients allergic to CM the IgE-immunoreactivity of homologous proteins and peptides from either CM or GM are positively correlated. In contrast, all bovine

'INRA, Unité d'Immuno-Allergie Alimentaire, Gif-sur-Yvette, France

Full list of author information is available at the end of the article proteins and related peptides were poorly IgE-immunoreactive in patients allergic to GM but tolerant to CM. These patients showed a specific IgE response restricted to the caprine $\alpha s 1$-, $\alpha s 2$-and $\beta$-caseins. The fragment $f$ (29-107) from goat $\beta$-casein and to a lesser extent, the complementary one $f(108-207)$ were highly immunoreative. The IgE response to goat $\beta$-casein is partly directed against the short peptide $f(59-79)$ which differs from its bovine counterpart by only 2 amino acids substitutions.

\section{Conclusion}

Allergy to GM in patients tolerant to $\mathrm{CM}$ is associated with an IgE response specific to caprine caseins without any cross reactivity to bovine counterparts despite sequence homology of ca. $90 \%$. As observed with peptides derived from $\beta$-casein, the lack of cross-reactivity between bovine and caprine caseins can be explained by few modifications in the primary structure of the proteins.

\section{Author details}

${ }^{1}$ INRA, Unité d'Immuno-Allergie Alimentaire, Gif-sur-Yvette, France. ${ }^{2}$ Hôpital Necker Enfants Malades, Paris, France.

Published: 12 August 2011

doi:10.1186/2045-7022-1-S1-09

Cite this article as: Ah-Leung et al:: Specific lgE responses in patients allergic to goat's milk but tolerant to cow's milk: involvement of minor differences in primary structure between caprine and bovine caseins. Clinical and Translational Allergy 2011 1(Suppl 1):09.

\section{C) Biomed Central}

( 2011 Ah-Leung et al; licensee BioMed Central Ltd. This is an open access article distributed under the terms of the Creative Commons Attribution License (http://creativecommons.org/licenses/by/2.0), which permits unrestricted use, distribution, and reproduction in any medium, provided the original work is properly cited. 